\title{
Cardiac Regeneration After Myocardial Infarction: an Approachable Goal
}

\author{
Mauro Giacca $^{1,2}$ (D) \\ Published online: 10 August 2020 \\ (C) The Author(s) 2020
}

\begin{abstract}
Purpose of Review Until recently, cardiac regeneration after myocardial infarction has remained a holy grail in cardiology. Failure of clinical trials using adult stem cells and scepticism about the actual existence of such cells has reinforced the notion that the heart is an irreversibly post-mitotic organ. Recent evidence has drastically challenged this conclusion.

Recent Findings Cardiac regeneration can successfully be obtained by at least two strategies. First, new cardiomyocytes can be generated from embryonic stem cells or induced pluripotent stem cells and administered to the heart either as cell suspensions or upon ex vivo generation of contractile myocardial tissue. Alternatively, the endogenous capacity of cardiomyocytes to proliferate can be stimulated by the delivery of individual genes or, more successfully, of selected microRNAs.

Summary Recent experimental success in large animals by both strategies now fuels the notion that cardiac regeneration is indeed possible. Several technical hurdles, however, still need to be addressed and solved before broad and successful clinical application is achieved.
\end{abstract}

Keywords Cardiomyocyte $\cdot$ Myocardial infarction $\cdot$ microRNA $\cdot$ Lipid nanoparticle $\cdot$ Regeneration $\cdot$ Stem cells

\section{Introduction}

The need to develop novel therapies for heart failure (HF) consequent to myocardial infarction (MI) is impelling. Despite notable progress in the application of devices assisting the failing myocardium [1], HF prognosis remains poor, with mortality estimated at $40 \%$ of patients at only 4 years from diagnosis [2]. This is worse than several common cancers. HF is also tremendously expensive, representing $2-3 \%$ of national health expenditures in high-income countries, projected to more than doubling in the next 20 years [3, 4].

Most notably, pharmacological treatment of HF uses drugs that have only marginally evolved since the mid-1990s. While

This article is part of the Topical Collection on Myocardial Disease

Mauro Giacca

mauro.giacca@kcl.ac.uk

1 King's College London, British Heart Foundation Centre of Research Excellence, School of Cardiovascular Medicine \& Sciences, SE5 9NU London, United Kingdom

2 Department of Medical, Surgical and Health Sciences, University of Trieste, 34127 Trieste, Italy high hope is now raised by the unpredicted and somehow surprising cardiovascular effects of SGLT2 inhibitors [5], for which no convincing molecular explanation yet exists, no conceptually novel drugs have been introduced in the management of patients with HF since the angiotensin II receptor blockers [6]. The relatively novel angiotensin receptorneprilysin inhibitor (ARNI) combination [7] is based on drugs that were both individually developed in the 1990s. In addition, a number of drugs have so far failed in Phase III clinical trials [8]. Even more remarkably, for conditions that are as prevalent as MI and HF, no biological therapy has yet been developed, based on any protein, peptide, antibody, or nucleic acid [9].

\section{The Problems of Cardiomyocyte Loss}

It has become progressively clear that a major problem underlying the prevalence of HF is linked to the ageing of the population and the lack of regenerative potential of the heart. Acute myocardial injury can kill as many as $25 \%$ of cardiomyocytes (CMs) from the left ventricle, corresponding to up to 1 billion cells [10]. In addition, chronic myocardial disease can kill CMs over prolonged periods of time. This is now clear in a number of pathological conditions, ranging 
from inherited cardiomyopathies to oncological treatments [11]. CM loss also accompanies physiological ageing [12].

This progressive or sudden loss of contractile cells during life is not paralleled by significant new contractile tissue formation. At least three different types of information are concordant in indicating that the extent of $\mathrm{CM}$ renewal in adult life is minimal and certainly clinically negligible. First, ${ }^{14} \mathrm{C}$-carbon dating of human CM DNA indicated that renewal of these cells in a 70-year-old individual is less than $50 \%$ [13], in fact showing that the majority of CMs at any time in adulthood are those generated at birth or immediately afterwards. Second, measurements obtained using mass spectrometry imaging in mice revealed a rate of $\mathrm{CM}$ renewal of approximately $1 \%$ per year, which raises three times after MI [14]. These values are consistent with those detected by ${ }^{14} \mathrm{C}$ dating. Third, the same information was also obtained by analysing the rate of DNA synthesis in vivo in mice [15].

Lack of CM renewal reflects the incapacity of CMs to replicate. $\mathrm{CM}$ replication occurs during embryonic, foetal, and immediate post-natal life, to eventually drop down suddenly in the early neonatal stage [16]. As a consequence, immediately after birth, CM can replicate and drive cardiac regeneration, while this property is irreversibly lost at 7 days in mice. Similar observations also hold true in pigs, in which MI is repaired by complete regeneration in 2-day-old piglets, while invariably leads to scarring in adult animals [17]. An anecdotical report in an infant with acute $\mathrm{MI}$ - a very rare condition-reveals that complete cardiac regeneration is also possible immediate after birth in humans [18].

The incapacity of the mammalian heart to regenerate in adulthood contrasts with the evidence in amphibians and fish, in which the regenerative capacity persists throughout life $[19,20]$. Of note, regeneration in these animals, similar to neonatal mice and pigs, does not involve the proliferation and differentiation of any cardiac stem cell, but is sustained by the partial de-dedifferentiation of existing CMs that resume proliferation [21, 22]. In adult mice, there is also an attempt at proliferation by $\mathrm{CMs}$ bordering the infarcted region [14, 15]; however, this is abortive and the extent of new CM formation is largely below the threshold necessary to provide clinical benefit.

Over the last years, there has been intense research to unravel the reason why $\mathrm{CM}$ proliferation stops irreversibly after birth. A prevalent view is that this is linked to sudden biochemical and mechanical events occurring immediately after birth. Pressure overload [23], sudden increase in oxygen tension and oxidative stress [24], lack of maternal factors [25], changes in hormonal stimulation [26], and switch from glycolytic to oxidative metabolism [27] are all factors that have been associated with the rapid loss of regenerative capacity. Most reasonably, it appears likely that the withdrawal of CMs from the cell cycle and the activation of a hypertrophic gene programme is the consequence of a combination of all these factors.

\section{Factors and Pathways Regulating Cardiomyocyte Proliferation}

Not unlikely all other cell types, the regulation of CM proliferation occurs through the combined action of a number of factors signalling to CMs from the outside of the plasma membrane or transducing their proliferative signal intracellularly (Fig. 1). These will be briefly reviewed in this section.

Growth Factors and Their Receptors Several growth factors have been identified that can stimulate CM proliferation, especially in conditions when proliferation already occurs spontaneously such as during the embryonic and neonatal stages. These include interleukin-6 (IL-6) [28, 29], platelet-derived growth factor (PDGF) [30], members of the fibroblast growth factor (FGF) family [31, 32], follistatin-like 1 (Fstl1) [33], and neuregulin-1 (NRG1) [34-36]. Paracrine control of CM proliferation was also reported for factors secreted by $\mathrm{T}$ regulatory cells [25] and cardiac resident monocytes [37]. Finally, CM replication was also recently reported to respond to changes in the extracellular matrix, which are mediated agrin [38]. In particular, this factor, which is a component of the neonatal ECM, appears to stimulate CM division through a mechanism that involves the disassembly of the CM membrane-associated dystrophin-glycoprotein complex (DGC) [38].

Signal Transduction Pathways At least three major signal transduction pathways were shown to participate in the regulation of $\mathrm{CM}$ proliferation during the embryonic, foetal, and neonatal life. During embryonic development, $\mathrm{CM}$ proliferation is regulated by the $\mathrm{Wnt} / \beta$-catenin pathway. In the absence of Wnt, the levels of cytoplasmic $\beta$ catenin are low since this protein is targeted for degradation by a destruction complex also including glycogen synthase kinase $3 \beta$ (GSK-3 $\beta$ ) [39]. In CMs, inhibition of GSK3- $\beta$, through genetic means [40] or by treatment with the inhibitory small molecule BIO [41], results in $\beta$ catenin stabilization and translocation to the nucleus, where the protein acts as a transcriptional coactivator of members of the $\mathrm{T}$ cell factor (TCF)/Lymphoid enhancer factor (LEF) family of proteins, followed by CM proliferation.

A second signal transduction mechanism relevant to $\mathrm{CM}$ proliferation is the Notch pathway. Notch signalling requires cell-cell contact and occurs through engagement of the Notch receptor to one of its ligands, in particular, Jagged1 in the mammalian heart, followed by translocation of the cleaved Notch intracellular domain (ICD) to the nucleus, where it acts 
FIG. 1 Intracellular and extracellular proteins, genes, and non-coding RNAs known to regulate cardiomyocyte proliferation and cardiac regeneration. See text for explanation

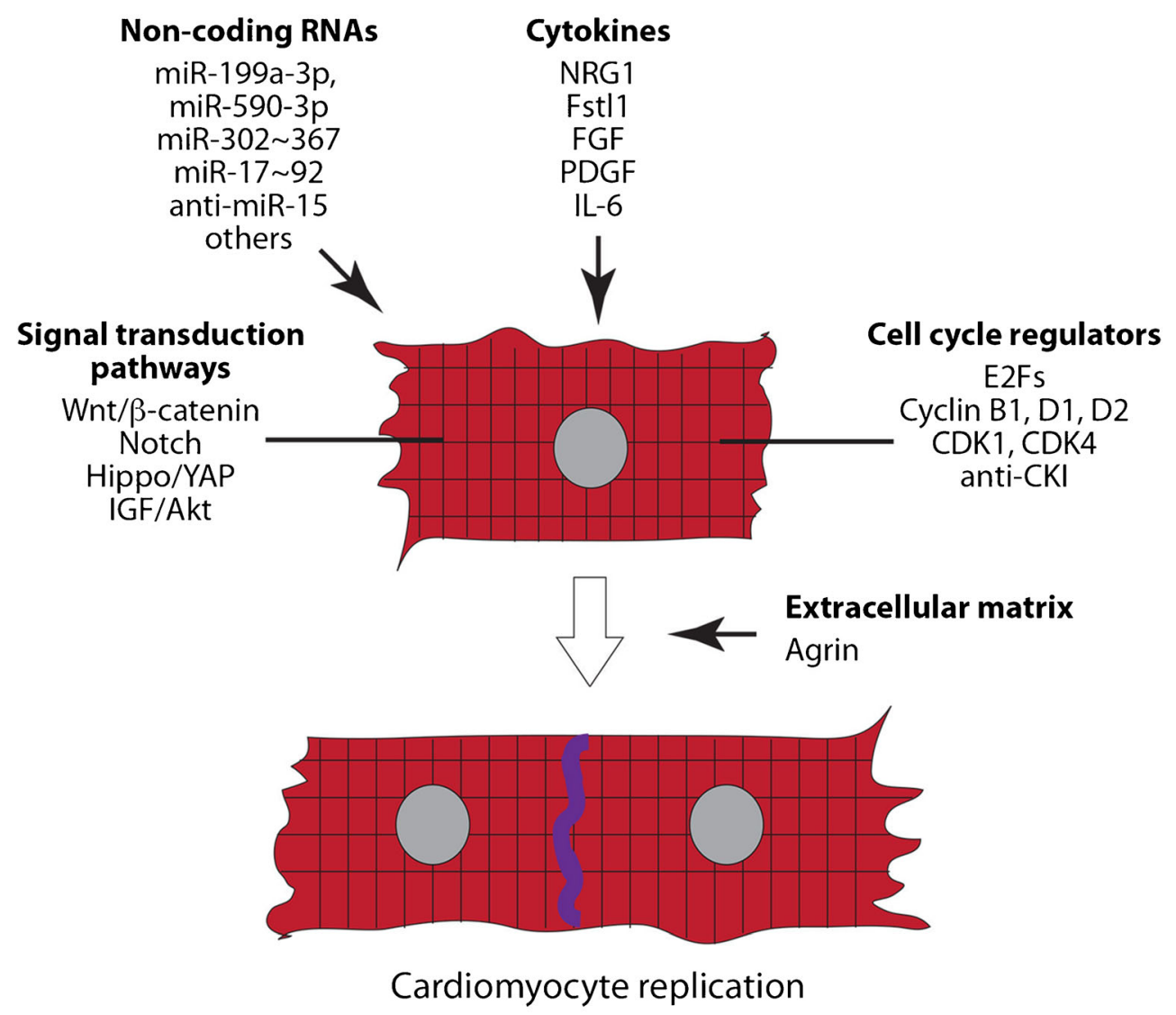

miR-199a-3p,

miR-590-3p

anti-miR-15

others
Non-coding RNAs tokines

FGF

PDGF

\section{gnal transduction pathways \\ nt $/ \beta$-catenin \\ ippo/YAP GF/Akt}

\author{
E2Fs \\ lin B1, D1, D2 \\ K1, CDK \\ anti-CKI
}

as a transcriptional coactivator [42]. Notch regulates proliferation of immature CMs during the foetal and post-natal life [43-45].

A third essential pathway involved in $\mathrm{CM}$ proliferation converges in the activation of another transcriptional cofactor, the YAP protein, and its cognate factor TAZ. This is the final positive effector of the inhibitory Hippo pathway. In resting CMs, YAP is maintained inactive by phosphorylation of a kinase cascade, which prevent its nuclear translocation and drives its proteolytic degradation. These kinases include LATS1/2 with its cofactor MOB1 and MST1/2 (Hippo in Drosophila) with its cofactor SAV1. Other inhibitory kinases are TAOK1 and STKL38. Regulation of the Hippo pathway is a main mechanism for CM mechanosensing, which transduces stretch and tension signals from the extracellular environment into the cell nucleus. Genetic deletion of MST1, SAV1, and LATS results in cardiac hyperplasia [46], while overexpression of MST1 [47] or LATS2 [48] leads to postnatal dilated cardiomyopathy. Transgenic overexpression of a constitutively active YAP mutant (YAPS112A) causes CM hyperproliferation $[49,50]$.

Cell Cycle Regulators Similar to all cell types, cell cycle regulation in CMs is also governed by a series of positive and negative regulators that converge on cyclin/CDK activation. Work performed over the last several years has shown that overexpression of E2F transcription factor [51-53] or cyclin D1 and D2 [54-56] can lead to CM proliferation. Similar results can be achieved by knocking down the cyclindependent kinase inhibitors p2 $1^{\mathrm{WAF} 1 / \mathrm{CIP} 1}, \mathrm{p} 27^{\mathrm{KIP} 1}$, and $\mathrm{p} 57^{\mathrm{KIP} 2}$ [57] or Meis1, a homeodomain transcription factor that activates expression of $\mathrm{p} 16^{\mathrm{INK} 4 \mathrm{a}}$ and $\mathrm{p} 21^{\mathrm{WAF} 1 / \mathrm{CIP} 1}$ [58]. The observation that transgenic animals overexpressing cyclin A2 [59, 60], cdk2 [61], cyclin D1 [54], and cyclin D2 [62, 63] have increased CM proliferation is also consistent with these findings.

\section{Stem Cells and Genes for Cardiac Regeneration}

Starting from the early 2000 s there has been a massive interest in developing innovative strategies for cardiac regeneration. Fuelled by the apparent existence of stem cells in multiple tissues from adult individuals, several clinical attempts were based on the injection, into the infarcted or failing heart, of cells recovered from the bone marrow (unfractionated, immunopurified for c-kit antigen expression or expressing markers of stromal mesenchymal cells $[64,65])$ or purified from the heart itself $[66,67]$. Despite marginal evidence of clinical benefit in some of these studies due to paracrine effects $[68,69]$, the current overall consensus is that no proof of actual cardiac regeneration (i.e. formation of new cardiomyocytes and cardiac tissue) was achieved by any of 
these studies. More in general, no convincing evidence exists that stem cells of any derivation from adult individuals exist that might regenerate the heart [70]. Examination of some of the original studies with c-kit-positive cells has led to the retraction of some of the published findings (http://circ. ahajournals.org/content/129/16/e466.full.pdf+html) and investigation on the integrity of others (https://doi.org/10. 1016/S0140-6736(14)60608-5).

Embryonic stem cells or iPS cells can be expanded in the laboratory to generate a number of $\mathrm{CMs}$, in the order of $0.5-1$ billion, to be directly injected into the heart. This approach has successfully translated into improved cardiac repair in a series of recent studies in infarcted monkeys infused with these cells into the infarcted area $[71,72 \bullet \cdot]$. A more complex approach along the same theme is the ex vivo generation of large patches of myocardial tissue starting form hiPS- or hESderived CMs based on their integration into $3 \mathrm{D}$ contractile tissue $[73 \bullet, 74]$. This is a promising approach to generate contractile tissue, thanks to the spontaneous property of CMs to organize into myocardial-like tissue once subjected to load in the laboratory. The concept of substituting lost cardiac tissue by infusing individual CMs or ex vivo generated cardiac tissue is of intuitive interest, however not devoid of a series of problems. The cells that can be obtained to date from hiPS or hES cells have an embryonic phenotype and generate arrhythmias once injected into the heart; the recipients need to be immunosuppressed to avoid rejection and integration into the cardiac electric and mechanical syncytium is still imperfect. More notably, both CM infusion and cardiac tissue implantation are complex procedures in their nature, which contrasts with the broad demand for cardiac regeneration.

A possibly simpler and translatable possibility is to reawaken the endogenous potential of CMs to proliferate and thus mimic what spontaneously occurs in the neonatal mammalian heart or in amphibians and fish throughout life. This is quite efficient in transgenic mouse models. For example, mice transgenic for activated YAP or knock out for the inhibitor Mst1 kinase or for the Mst1 co-factor Salvador can regenerate the heart after MI $[50,75,76 \bullet \cdot$. For some of the activators, regeneration was also reported when their genes were administered using viral vectors. Among others, this was reported for YAP [77] or the Notch intracellular domain [43, 45]. However, exogenous delivery is not fraught with problems. Permanent overexpression YAP needs to be taken with caution, given the tumour suppressor role that the Hippo pathway exerts in several cancers [78]. In the case of Notch, this pathway is instead inactivated in adult hearts by suppressive epigenetic modifications at Notch-responsive promoters [79]. Finally, CM replication and cardiac regeneration was shown to be achievable by the simultaneous delivery of multiple cell cycle regulators [80]; this approach, however, appears quite problematic for therapeutic applications.

\section{Stimulation of Endogenous Cardiac Regeneration by microRNAs}

An appealing strategy to achieve cardiac regeneration is to manipulate the CM proliferative potential by microRNAs (miRNAs). These short, double-stranded RNA molecules control virtually any aspect of cell biology, including proliferation. This also holds true for CMs (reviewed in ref. [81]). The miRNAs stimulating endogenous CM proliferation can be classified into one of three categories. First, several proregenerative miRNAs include molecules that are highly expressed in ES cells and are required to maintain pluripotency. These include members of the miR-302 367 and miR-miR-290 families, which share the same seed sequence [82, 83]. Activation of the miR-302-367 cluster after MI in mice induces cardiac regeneration, as does the transient delivery of some of its members as synthetic molecules [84]. A second group of miRNAs that can induce $\mathrm{CM}$ regeneration includes a series of miRNAs involved in tumorigenesis. These include the miR-17 92 cluster (also named OncomiR1) [85, $86]$, and its paralogue clusters miR-106b 25 and miR106a 363 [87, 88]. Also, in this case, both transgenic expression of the miR-17 92 cluster cluster [89] or the administration of the cluster member miR-19a/19b [90] led to cardiac regeneration. A third group of miRNAs was identified through two large screenings of human miRNAs [91, 92]. The most prominent and studied of these miRNAs is miR199a-3p, which was shown to stimulate cardiac repair both when expressed from an AAV9 vector [91] or a synthetic RNA molecule [93] in mice and from an AAV6 vector in pigs [94*0]. Several other miRNAs are also capable, to a various extent, to induce cardiomyocyte proliferation (extensively reviewed in ref. [81]), indicating that the withdrawal of CMs from the cell cycle at birth is not an irreversible process but a regulated one, with the possibility of reverting it through the manipulation of gene expression.

The identification of miRNAs with the potential to stimulate cardiac regeneration appears particularly appealing for translational purposes, as these molecules can be developed as treatments fitting virtually all patients and do not require extensive ex vivo manipulation, as instead is required for stem cell applications. MicroRNAs can be delivered either as expressed from viral vectors or as synthetic molecules. In the former case, AAV vectors now appear as the vectors of choice for cardiac gene delivery [95]. Using AAVs to deliver genes promoting cardiac regeneration, however, is not devoid of problems. These vectors persist virtually indefinitely in CMs, while, to date, no promoter has been described in humans or non-human primates from which expression can be turned off. This creates obvious safety issues and efficacy concerns as far as CMs are concerned, as the stimulation of proliferation in these cells requires the transient disassembly of the sarcomeric apparatus and cell dedifferentiation $[22,96$, 
97]. There appears to be a need, therefore, to apply the proproliferative stimulus transitorily. In addition, endogenous transcription of a miRNA gene is followed by processing of the pri-miRNA by the cellular RNAi machinery. This leads to the generation of both miRNA strands, which can be not necessarily desirable. These problems surfaced in the only large animal study so far performed to test the efficacy of one miRNA, miR-199a, to drive cardiac regeneration in pigs [94.•]. In this study, cardiac regeneration and improvement of cardiac function was very significant at 1 month after treatment of infarcted pigs; however, several animals developed fatal arrhythmias at longer times. The hearts of the treated animals showed the presence of proliferating and undifferentiated cells, along with the expression of both the proregenerative miR-199a-3p strand but also of its complementary miR-199a-5p strand, which is known to exert undesirable effects in the heart [94*0].

One of the possible strategies to overcome this limitation of $\mathrm{AAV}$-mediated gene delivery is to resort to the possibility of administering the miRNAs as synthetic RNA molecules. Already available evidence shows that a single intramyocardial injection miR-199a-3p or miR-590-3p mimics using a lipofectamine-based formulation can stimulate a regenerative response in mice [93]. Similar results were also obtained by a single intramyocardial injection of miR-19a/19b [90] or miR$302 \mathrm{~b} / \mathrm{c}$ mimics [98] or the daily intravenous administration of miR302b/c [84], miR-19a/19b [90], or miR-708 [99].

\section{Conclusions}

The notion that regeneration of the cardiac muscle can be achieved by either the implantation of ex vivo generated CMs or through the stimulation of the proliferative capacity of endogenous cells to proliferate remains exciting. It challenges a longstanding dogma that damage in post-mitotic tissue is intrinsically irreversible and offers hope for treatment to the vast number of patients with post-ischemic HF. Both the stem-cell and the endogenous regeneration approaches, however, still require significant improvement before extensive clinical application. In the case of stem cells, ES- or iPS-derived CMs are still immature, their electrical and mechanical coupling to endogenous $\mathrm{CM}$ is limited and the process of deriving the large number of cells required for each patient is demanding for scaling up. Maturation appears improved when CMs are used to form ex vivo, 3D cardiac tissue; however, the problem of integrating large patches of engineered myocardium into the preexisting one still remains.

In the case of endogenous cardiac regeneration, this approach appears more amenable to application in a large number of patients and less demanding in terms of development. However, a main problem remains the efficacy of delivery of genes or miRNAs to the infarcted myocardium. The experiments with lipid-mediated delivery in mice appear promising, but translation of these findings into large animals will require extensive experimentation. In this respect, it is however exciting to note that the field of small RNA delivery has made substantial progress over the last decade, with the generation of lipid nanoparticles (LNPs) with neutral surface charge, and of methods to load small nucleic acids into these particles [100]. The first LNP delivering an RNAi therapeutic molecule to reach the market was patisiran in 2018 - this drug lowers the hepatic levels of transthyretin for the treatment of hereditary transthyretin-induced amyloidosis [101]. Several other LNP formulations of siRNAs and miRNAs for other applications are in the pipeline of clinical experimentation. Whether an LNP delivering one of the pro-proliferative miRNAs for CMs might be effective in inducing cardiac regeneration in large animals and is thus amenable to clinical translation awaits the results of ongoing experimentation.

Funding Information This work was supported by the European Research Council (ERC) Advanced Grant 787971 "CuRE," by the British Heart Foundation (BHF) Programme Grant RG/19/11/34633 and the King's College London BHF Centre of Research Excellence grant RE/18/2/34213 and by grants 825670 "CardioReGenix" and 874764 "REANIMA" from the European Commission Horizon 2020 programme, along with the continuous support of Fondazione CRTrieste, Trieste, Italy.

\section{Compliance with Ethical Standards}

Conflict of Interest The author declares that no conflict of interest.

Human and Animal Rights and Informed Consent This article does not contain any studies with human or animal subjects performed by any of the authors.

Open Access This article is licensed under a Creative Commons Attribution 4.0 International License, which permits use, sharing, adaptation, distribution and reproduction in any medium or format, as long as you give appropriate credit to the original author(s) and the source, provide a link to the Creative Commons licence, and indicate if changes were made. The images or other third party material in this article are included in the article's Creative Commons licence, unless indicated otherwise in a credit line to the material. If material is not included in the article's Creative Commons licence and your intended use is not permitted by statutory regulation or exceeds the permitted use, you will need to obtain permission directly from the copyright holder. To view a copy of this licence, visit http://creativecommons.org/licenses/by/4.0/.

\section{References}

Papers of particular interest, published recently, have been highlighted as:

- Of importance

•. Of major importance

1. Birks EJ. Molecular changes after left ventricular assist device support for heart failure. Circ Res. 2013;113(6):777-91. 
2. Roger VL. Epidemiology of heart failure. Circ Res. 2013;113(6): 646-59.

3. Heidenreich PA, Albert NM, Allen LA, Bluemke DA, Butler J, Fonarow GC, et al. Forecasting the impact of heart failure in the United States: a policy statement from the American Heart Association. Circ Heart Fail. 2013;6(3):606-19.

4. Roth GA, Johnson C, Abajobir A, Abd-Allah F, Abera SF, Abyu G, et al. Global, regional, and National Burden of cardiovascular diseases for 10 causes, 1990 to 2015. J Am Coll Cardiol. 2017;70(1):1-25.

5. McMurray JJV, Solomon SD, Inzucchi SE, Kober L, Kosiborod MN, Martinez FA, et al. Dapagliflozin in patients with heart failure and reduced ejection fraction. N Engl J Med. 2019;381(21): 1995-2008.

6. Gottlieb SS, Dickstein K, Fleck E, Kostis J, Levine TB, LeJemtel $\mathrm{T}$, et al. Hemodynamic and neurohormonal effects of the angiotensin II antagonist losartan in patients with congestive heart failure. Circulation. 1993;88(4 Pt 1):1602-9.

7. Califf RM. LCZ696: too good to be true? Eur Heart J. 2015;36(7): 410-2.

8. Kaye DM, Krum H. Drug discovery for heart failure: a new era or the end of the pipeline? Nat Rev Drug Discov. 2007;6(2):127-39.

9. Packer M. The future treatment of heart failure? Eur Heart J. 2018;39(1):5-7.

10. Murry CE, Reinecke H, Pabon LM. Regeneration gaps: observations on stem cells and cardiac repair. J Am Coll Cardiol. 2006;47(9):1777-85.

11. Whelan RS, Kaplinskiy V, Kitsis RN. Cell death in the pathogenesis of heart disease: mechanisms and significance. Annu Rev Physiol. 2010;72:19-44.

12. Olivetti G, Giordano G, Corradi D, Melissari M, Lagrasta C, Gambert SR, et al. Gender differences and aging: effects on the human heart. J Am Coll Cardiol. 1995;26(4):1068-79.

13. Bergmann O, Bhardwaj RD, Bernard S, Zdunek S, BarnabeHeider F, Walsh S, et al. Evidence for cardiomyocyte renewal in humans. Science. 2009;324(5923):98-102.

14. Senyo SE, Steinhauser ML, Pizzimenti CL, Yang VK, Cai L, Wang M, et al. Mammalian heart renewal by pre-existing cardiomyocytes. Nature. 2013;493(7432):433-6.

15. Soonpaa MH, Field LJ. Assessment of cardiomyocyte DNA synthesis in normal and injured adult mouse hearts. Am J Phys. 1997;272(1 Pt 2):H220-6.

16. Sedmera D, Reckova M, DeAlmeida A, Coppen SR, Kubalak SW, Gourdie RG, et al. Spatiotemporal pattern of commitment to slowed proliferation in the embryonic mouse heart indicates progressive differentiation of the cardiac conduction system. Anat Rec A Discov Mol Cell Evol Biol. 2003;274(1):773-7.

17. Ye L, D'Agostino G, Loo SJ, Wang CX, Su LP, Tan SH, et al. Early regenerative capacity in the porcine heart. Circulation. 2018;138(24):2798-808.

18. Haubner BJ, Schneider J, Schweigmann U, Schuetz T, Dichtl W, Velik-Salchner C, et al. Functional recovery of a human neonatal heart after severe myocardial infarction. Circ Res. 2016;118(2): 216-21.

19. Poss KD, Wilson LG, Keating MT. Heart regeneration in zebrafish. Science. 2002;298(5601):2188-90.

20. Oberpriller JO, Oberpriller JC. Response of the adult newt ventricle to injury. J Exp Zool. 1974;187(2):249-53.

21. Kikuchi K, Holdway JE, Werdich AA, Anderson RM, Fang Y, Egnaczyk GF, et al. Primary contribution to zebrafish heart regeneration by gata4(+) cardiomyocytes. Nature. 2010;464(7288): 601-5.

22. Jopling C, Sleep E, Raya M, Marti M, Raya A, Izpisua Belmonte JC. Zebrafish heart regeneration occurs by cardiomyocyte dedifferentiation and proliferation. Nature. 2010;464(7288):606-9.
23. Canseco DC, Kimura W, Garg S, Mukherjee S, Bhattacharya S, Abdisalaam S, et al. Human ventricular unloading induces cardiomyocyte proliferation. J Am Coll Cardiol. 2015;65(9):892-900.

24. Puente BN, Kimura W, Muralidhar SA, Moon J, Amatruda JF, Phelps KL, et al. The oxygen-rich postnatal environment induces cardiomyocyte cell-cycle arrest through DNA damage response. Cell. 2014;157(3):565-79.

25. Zacchigna S, Martinelli V, Moimas S, Colliva A, Anzini M, Nordio A, et al. Paracrine effect of regulatory $\mathrm{T}$ cells promotes cardiomyocyte proliferation during pregnancy and after myocardial infarction. Nat Commun. 2018;9(1):2432.

26. Hirose K, Payumo AY, Cutie S, Hoang A, Zhang H, Guyot R, et al. Evidence for hormonal control of heart regenerative capacity during endothermy acquisition. Science. 2019;364(6436):184-8.

27. Lopaschuk GD, Jaswal JS. Energy metabolic phenotype of the cardiomyocyte during development, differentiation, and postnatal maturation. J Cardiovasc Pharmacol. 2010;56(2):130-40.

28. Zhou B, Honor LB, He H, Ma Q, Oh JH, Butterfield C, et al. Adult mouse epicardium modulates myocardial injury by secreting paracrine factors. J Clin Invest. 2011;121(5):1894-904.

29. Przybyt E, Krenning G, Brinker MG, Harmsen MC. Adipose stromal cells primed with hypoxia and inflammation enhance cardiomyocyte proliferation rate in vitro through STAT3 and Erk1/2. J Transl Med. 2013;11:39.

30. Hinrichsen R, Haunso S, Busk PK. Different regulation of $\mathrm{p} 27$ and Akt during cardiomyocyte proliferation and hypertrophy. Growth Factors. 2007;25(2):132-40.

31. Kardami E, Banerji S, Doble BW, Dang X, Fandrich RR, Jin Y, et al. PKC-dependent phosphorylation may regulate the ability of connexin43 to inhibit DNA synthesis. Cell Commun Adhes. 2003;10(4-6):293-7.

32. Engel FB, Hsieh PC, Lee RT, Keating MT. FGF1/p38 MAP kinase inhibitor therapy induces cardiomyocyte mitosis, reduces scarring, and rescues function after myocardial infarction. Proc Natl Acad Sci U S A. 2006;103(42):15546-51.

33. Wei K, Serpooshan V, Hurtado C, Diez-Cunado M, Zhao M, Maruyama S, et al. Epicardial FSTL1 reconstitution regenerates the adult mammalian heart. Nature. 2015;525(7570):479-85.

34. Zhao YY, Sawyer DR, Baliga RR, Opel DJ, Han X, Marchionni MA, et al. Neuregulins promote survival and growth of cardiac myocytes. Persistence of ErbB2 and ErbB4 expression in neonatal and adult ventricular myocytes. J Biol Chem. 1998;273(17): 10261-9.

35. Bersell K, Arab S, Haring B, Kuhn B. Neuregulin1/ErbB4 signaling induces cardiomyocyte proliferation and repair of heart injury. Cell. 2009;138(2):257-70.

36. D'Uva G, Aharonov A, Lauriola M, Kain D, Yahalom-Ronen Y, Carvalho S, et al. ERBB2 triggers mammalian heart regeneration by promoting cardiomyocyte dedifferentiation and proliferation. Nat Cell Biol. 2015;17(5):627-38.

37. Lavine KJ, Epelman S, Uchida K, Weber KJ, Nichols CG, Schilling JD, et al. Distinct macrophage lineages contribute to disparate patterns of cardiac recovery and remodeling in the neonatal and adult heart. Proc Natl Acad Sci U S A. 2014;111(45): 16029-34.

38. Bassat E, Mutlak YE, Genzelinakh A, Shadrin IY, Baruch Umansky K, Yifa O, et al. The extracellular matrix protein agrin promotes heart regeneration in mice. Nature. 2017;547(7662): 179-84.

39. Kim SE, Huang H, Zhao M, Zhang X, Zhang A, Semonov MV, et al. Wnt stabilization of beta-catenin reveals principles for morphogen receptor-scaffold assemblies. Science. 2013;340(6134): 867-70.

40. Singh AP, Umbarkar P, Guo Y, Force T, Gupte M, Lal H. Inhibition of GSK-3 to induce cardiomyocyte proliferation: a 
recipe for in situ cardiac regeneration. Cardiovasc Res. 2019;115(1):20-30.

41. Tseng AS, Engel FB, Keating MT. The GSK-3 inhibitor BIO promotes proliferation in mammalian cardiomyocytes. Chem Biol. 2006;13(9):957-63.

42. De Strooper B, Annaert W, Cupers P, Saftig P, Craessaerts K, Mumm JS, et al. A presenilin-1-dependent gamma-secretase-like protease mediates release of notch intracellular domain. Nature. 1999;398(6727):518-22.

43. Collesi C, Zentilin L, Sinagra G, Giacca M. Notch1 signaling stimulates proliferation of immature cardiomyocytes. J Cell Biol. 2008;183(1):117-28.

44. Croquelois A, Domenighetti AA, Nemir M, Lepore M, Rosenblatt-Velin N, Radtke F, et al. Control of the adaptive response of the heart to stress via the Notch1 receptor pathway. J Exp Med. 2008;205(13):3173-85.

45. Campa VM, Gutierrez-Lanza R, Cerignoli F, Diaz-Trelles R, Nelson B, Tsuji T, et al. Notch activates cell cycle reentry and progression in quiescent cardiomyocytes. J Cell Biol. 2008;183(1):129-41.

46. Heallen T, Zhang M, Wang J, Bonilla-Claudio M, Klysik E, Johnson RL, et al. Hippo pathway inhibits Wnt signaling to restrain cardiomyocyte proliferation and heart size. Science. 2011;332(6028):458-61

47. Yamamoto S, Yang G, Zablocki D, Liu J, Hong C, Kim SJ, et al. Activation of Mstl causes dilated cardiomyopathy by stimulating apoptosis without compensatory ventricular myocyte hypertrophy. J Clin Invest. 2003;111(10):1463-74.

48. Matsui YY, Nakano NN, Shao DD, Gao SS, Luo WW, Hong CC, et al. Lats 2 is a negative regulator of myocyte size in the heart. Circ Res. 2008;103(11):1309-18.

49. Xin M, Kim Y, Sutherland LB, Qi X, McAnally J, Schwartz RJ, et al. Regulation of insulin-like growth factor signaling by Yap governs cardiomyocyte proliferation and embryonic heart size. Sci Signal. 2011;4(196):ra70.

50. Xin M, Kim Y, Sutherland LB, Murakami M, Qi X, McAnally J, et al. Hippo pathway effector Yap promotes cardiac regeneration. Proc Natl Acad Sci U S A. 2013;110(34):13839-44.

51. Kirshenbaum LA, Abdellatif M, Chakraborty S, Schneider MD. Human E2F-1 reactivates cell cycle progression in ventricular myocytes and represses cardiac gene transcription. Dev Biol. 1996;179(2):402-11.

52. Agah R, Kirshenbaum LA, Abdellatif M, Truong LD, Chakraborty S, Michael LH, et al. Adenoviral delivery of E2F-1 directs cell cycle reentry and p53-independent apoptosis in postmitotic adult myocardium in vivo. J Clin Invest. 1997;100(11):2722-8.

53. van Amerongen MJ, Diehl F, Novoyatleva T, Patra C, Engel FB. E2F4 is required for cardiomyocyte proliferation. Cardiovasc Res. 2010;86(1):92-102.

54. Soonpaa MH, Koh GY, Pajak L, Jing S, Wang H, Franklin MT, et al. Cyclin D1 overexpression promotes cardiomyocyte DNA synthesis and multinucleation in transgenic mice. J Clin Invest. 1997;99(11):2644-54.

55. Tamamori-Adachi $\mathrm{M}$, Ito $\mathrm{H}$, Sumrejkanchanakij $\mathrm{P}$, Adachi $\mathrm{S}$, Hiroe M, Shimizu M, et al. Critical role of cyclin D1 nuclear import in cardiomyocyte proliferation. Circ Res. 2003;92(1): e12-9.

56. Busk PK, Hinrichsen R, Bartkova J, Hansen AH, Christoffersen TE, Bartek J, et al. Cyclin D2 induces proliferation of cardiac myocytes and represses hypertrophy. Exp Cell Res. 2005;304(1):149-61.

57. Di Stefano V, Giacca M, Capogrossi MC, Crescenzi M, Martelli F. Knockdown of cyclin-dependent kinase inhibitors induces cardiomyocyte re-entry in the cell cycle. J Biol Chem. 2011;286(10): 8644-54.
58. Mahmoud AI, Kocabas F, Muralidhar SA, Kimura W, Koura AS, Thet S, et al. Meis1 regulates postnatal cardiomyocyte cell cycle arrest. Nature. 2013;497(7448):249-53.

59. Chaudhry HW, Dashoush NH, Tang H, Zhang L, Wang X, Wu EX, et al. Cyclin A2 mediates cardiomyocyte mitosis in the postmitotic myocardium. J Biol Chem. 2004;279(34):35858-66.

60. Woo YJ, Panlilio CM, Cheng RK, Liao GP, Atluri P, Hsu VM, et al. Therapeutic delivery of cyclin A2 induces myocardial regeneration and enhances cardiac function in ischemic heart failure. Circulation. 2006;114(1 Suppl):I206-13.

61. Liao HS, Kang PM, Nagashima H, Yamasaki N, Usheva A, Ding $\mathrm{B}$, et al. Cardiac-specific overexpression of cyclin-dependent kinase 2 increases smaller mononuclear cardiomyocytes. Circ Res. 2001;88(4):443-50.

62. Pasumarthi KB, Nakajima H, Nakajima HO, Soonpaa MH, Field LJ. Targeted expression of cyclin D2 results in cardiomyocyte DNA synthesis and infarct regression in transgenic mice. Circ Res. 2005;96(1):110-8

63. Hassink RJ, Pasumarthi KB, Nakajima H, Rubart M, Soonpaa $\mathrm{MH}$, de la Riviere $\mathrm{AB}$, et al. Cardiomyocyte cell cycle activation improves cardiac function after myocardial infarction. Cardiovasc Res. 2008;78(1):18-25.

64. Pittenger MF, Martin BJ. Mesenchymal stem cells and their potential as cardiac therapeutics. Circ Res. 2004;95(1):9-20.

65. Hatzistergos KE, Quevedo H, Oskouei BN, Hu Q, Feigenbaum GS, Margitich IS, et al. Bone marrow mesenchymal stem cells stimulate cardiac stem cell proliferation and differentiation. Circ Res. 2010;107(7):913-22.

66. Beltrami AP, Barlucchi L, Torella D, Baker M, Limana F, Chimenti S, et al. Adult cardiac stem cells are multipotent and support myocardial regeneration. Cell. 2003;114(6):763-76.

67. Bolli R, Chugh AR, D'Amario D, Loughran JH, Stoddard MF, Ikram S, et al. Cardiac stem cells in patients with ischaemic cardiomyopathy (SCIPIO): initial results of a randomised phase 1 trial. Lancet. 2011;378(9806):1847-57.

68. Zimmet H, Porapakkham P, Porapakkham P, Sata Y, Haas SJ, Itescu $\mathrm{S}$, et al. Short- and long-term outcomes of intracoronary and endogenously mobilized bone marrow stem cells in the treatment of ST-segment elevation myocardial infarction: a metaanalysis of randomized control trials. Eur J Heart Fail. 2012;14(1):91-105.

69. Karantalis V, Hare JM. Use of mesenchymal stem cells for therapy of cardiac disease. Circ Res. 2015;116(8):1413-30.

70. Eschenhagen T, Bolli R, Braun T, Field LJ, Fleischmann BK, Frisen J, et al. Cardiomyocyte regeneration: a consensus statement. Circulation. 2017;136(7):680-6.

71. Chong JJ, Yang X, Don CW, Minami E, Liu YW, Weyers JJ, et al. Human embryonic-stem-cell-derived cardiomyocytes regenerate non-human primate hearts. Nature. 2014;510(7504):273-7.

72.• Liu YW, Chen B, Yang X, Fugate JA, Kalucki FA, FutakuchiTsuchida A, et al. Human embryonic stem cell-derived cardiomyocytes restore function in infarcted hearts of nonhuman primates. Nat Biotechnol. 2018:36(7):597-605 This important study shows that the infusion of embryonic stem cellsderived cardiomyocytes into an infarcted heart can lead to cardiac repair in monkeys.

73. Tiburcy M, Hudson JE, Balfanz P, Schlick S, Meyer T, Chang Liao ML, et al. Defined engineered human myocardium with advanced maturation for applications in heart failure modeling and repair. Circulation. 2017;135(19):1832-47 This study is a recent demonstration that cardiac repair can be achieved through the implantation of in vitro grown, 3D, functional cardiac tissue.

74. Weinberger F, Breckwoldt K, Pecha S, Kelly A, Geertz B, Starbatty $\mathrm{J}$, et al. Cardiac repair in guinea pigs with human 
engineered heart tissue from induced pluripotent stem cells. Sci Transl Med. 2016;8(363):363ra148.

75. Heallen T, Morikawa Y, Leach J, Tao G, Willerson JT, Johnson RL, et al. Hippo signaling impedes adult heart regeneration. Development. 2013;140(23):4683-90.

76.•• Leach JP, Heallen T, Zhang M, Rahmani M, Morikawa Y, Hill $\mathrm{MC}$, et al. Hippo pathway deficiency reverses systolic heart failure after infarction. Nature. 2017;550(7675):260-4 This is a very important study showing that cardiac regeneration can be achieved in mice by the activation of the YAP transcriptional cofactor even after post-myocardial heart failure is established.

77. Lin Z, von Gise A, Zhou P, Gu F, Ma Q, Jiang J, et al. Cardiacspecific YAP activation improves cardiac function and survival in an experimental murine MI model. Circ Res. 2014;115(3):354 63.

78. Kakiuchi-Kiyota S, Schutten MM, Zhong Y, Crawford JJ, Dey A. Safety considerations in the development of hippo pathway inhibitors in cancers. Front Cell Dev Biol. 2019;7:156.

79. Felician G, Collesi C, Lusic M, Martinelli V, Ferro MD, Zentilin $\mathrm{L}$, et al. Epigenetic modification at Notch responsive promoters blunts efficacy of inducing Notch pathway reactivation after myocardial infarction. Circ Res. 2014;115(7):636-49.

80. Mohamed TMA, Ang YS, Radzinsky E, Zhou P, Huang Y, Elfenbein A, et al. Regulation of cell cycle to stimulate adult cardiomyocyte proliferation and cardiac regeneration. Cell. 2018;173(1):104-16 e12.

81. Braga L, Ali H, Secco I, Giacca M. Non-coding RNA therapeutics for cardiac regeneration. Cardiovasc Res. 2020. https://doi.org/10. 1093/cvr/cvaa071.

82. Barroso-del Jesus A, Lucena-Aguilar G, Menendez P. The miR302-367 cluster as a potential stemness regulator in ESCs. Cell Cycle. 2009;8(3):394-8.

83. Wang Y, Baskerville S, Shenoy A, Babiarz JE, Baehner L, Blelloch R. Embryonic stem cell-specific microRNAs regulate the G1-S transition and promote rapid proliferation. Nat Genet. 2008;40(12):1478-83.

84. Tian Y, Liu Y, Wang T, Zhou N, Kong J, Chen L, et al. A microRNA-Hippo pathway that promotes cardiomyocyte proliferation and cardiac regeneration in mice. Sci Transl Med. 2015;7(279):279ra38.

85. Volinia S, Calin GA, Liu CG, Ambs S, Cimmino A, Petrocca F, et al. A microRNA expression signature of human solid tumors defines cancer gene targets. Proc Natl Acad Sci U S A. 2006;103(7):2257-61.

86. He L, Thomson JM, Hemann MT, Hernando-Monge E, Mu D, Goodson S, et al. A microRNA polycistron as a potential human oncogene. Nature. 2005;435(7043):828-33.

87. Gruszka R, Zakrzewska M. The oncogenic relevance of miR-1792 cluster and its paralogous miR-106b-25 and miR-106a-363 clusters in brain tumors. Int J Mol Sci. 2018;19(3):879.

88. Mehlich D, Garbicz F, Wlodarski PK. The emerging roles of the polycistronic miR-106b approximately 25 cluster in cancer-a comprehensive review. Biomed Pharmacother. 2018;107:118395.
89. Chen J, Huang ZP, Seok HY, Ding J, Kataoka M, Zhang Z, et al. Mir-17-92 cluster is required for and sufficient to induce cardiomyocyte proliferation in postnatal and adult hearts. Circ Res. 2013;112(12):1557-66.

90. Gao F, Kataoka M, Liu N, Liang T, Huang ZP, Gu F, et al. Therapeutic role of miR-19a/19b in cardiac regeneration and protection from myocardial infarction. Nat Commun. 2019;10(1): 1802 .

91. Eulalio A, Mano M, Dal Ferro M, Zentilin L, Sinagra G, Zacchigna $\mathrm{S}$, et al. Functional screening identifies miRNAs inducing cardiac regeneration. Nature. 2012;492(7429):376-81.

92. Diez-Cunado M, Wei K, Bushway PJ, Maurya MR, Perera R, Subramaniam S, et al. miRNAs that induce human cardiomyocyte proliferation converge on the hippo pathway. Cell Rep. 2018;23(7):2168-74.

93. Lesizza P, Prosdocimo G, Martinelli V, Sinagra G, Zacchigna S, Giacca M. Single-dose intracardiac injection of pro-regenerative microRNAs improves cardiac function after myocardial infarction. Circ Res. 2017;120(8):1298-304.

94.•• Gabisonia K, Prosdocimo G, Aquaro GD, Carlucci L, Zentilin L, Secco I, et al. MicroRNA therapy stimulates uncontrolled cardiac repair after myocardial infarction in pigs. Nature. 2019;569(7756): 418-22 Findings from this study indicate for the first time that cardiac regeneration in a large animal can be obtained after myocardial infarction by the administration of $\mathrm{AAV}$ vectors expressing one specific microRNA.

95. Zacchigna S, Zentilin L, Giacca M. Adeno-associated virus vectors as therapeutic and investigational tools in the cardiovascular system. Circ Res. 2014;114(11):1827-46.

96. Aguirre A, Montserrat N, Zacchigna S, Nivet E, Hishida T, Krause $\mathrm{MN}$, et al. In vivo activation of a conserved microRNA program induces mammalian heart regeneration. Cell Stem Cell. 2014;15(5):589-604.

97. Porrello ER, Mahmoud AI, Simpson E, Hill JA, Richardson JA, Olson EN, et al. Transient regenerative potential of the neonatal mouse heart. Science. 2011;331(6020):1078-80.

98. Wang LL, Liu Y, Chung JJ, Wang T, Gaffey AC, Lu M, et al. Local and sustained miRNA delivery from an injectable hydrogel promotes cardiomyocyte proliferation and functional regeneration after ischemic injury. Nat Biomed Eng. 2017;1:983-92.

99. Deng S, Zhao Q, Zhen L, Zhang C, Liu C, Wang G, et al. Neonatal heart-enriched miR-708 promotes proliferation and stress resistance of cardiomyocytes in rodents. Theranostics. 2017;7(7): 1953-65.

100. Kulkarni JA, Cullis PR, van der Meel R. Lipid nanoparticles enabling gene therapies: from concepts to clinical utility. Nucleic Acid Ther. 2018;28(3):146-57.

101. Adams D, Gonzalez-Duarte A, O'Riordan WD, Yang CC, Ueda $\mathrm{M}$, Kristen AV, et al. Patisiran, an RNAi therapeutic, for hereditary Transthyretin amyloidosis. N Engl J Med. 2018;379(1):1121.

Publisher's Note Springer Nature remains neutral with regard to jurisdictional claims in published maps and institutional affiliations. 